\title{
Faktor Keberhasilan Implementasi Kebijakan Penyelenggaraan Haji Di Kota Bandung
}

\section{${ }^{1}$ Jaliludin Muslim}

${ }^{1}$ UIN Sunan Gunung Djati Bandung, Indonesia; jaliludin@uinsgd.ac.id

\begin{abstract}
The service of organizing the pilgrimage is actually every year always strived to be better. The Government through the Indonesian Ministry of Religion in Bandung, should be able to implement the Implementation of Hajj Implementation Policy optimally and effectively, without ignoring the formal legal rules that have been established so far. This study aims to analyze the factors of success and failure of implementing the implementation of the pilgrimage policy in the city of Bandung. The approach used in this study is a qualitative approach, where researchers are directly involved in the study site through observation and participant observation. The type of data from this study are primary data and secondary data. Primary data in the form of information and data from interviews with interested parties and the main actors in the implementation of the pilgrimage in the city of Bandung. Secondary data sourced from articles, literature studies, documents and photos, statistical data, archives both from the government and the public as well as mass media publications. The results of this study indicate that in the process of implementing the implementation of the pilgrimage policy in the city of Bandung faces a number of challenges that are not easy so that several factors emerge that led to the success or failure of the implementation process. This study can be concluded that the implementation of the Hajj policy in the city of Bandung in 2016 has not been carried out properly, due to a paradoxical reality towards the ideal policy that has been determined.
\end{abstract}

Keywords: Islamic Administration, Public Policy, Policy Implementation, Local Government, Pilgrimage.

\section{Pendahuluan}

Undang-Undang Republik Indonesia Nomor 17 Tahun 1999 Tentang Penyelenggaraan Ibadah Haji menyebutkan bahwa penyelenggaraan ibadah haji bertujuan untuk memberikan pembinaan, pelayanan, dan perlindungan yang sebaik-baiknya melalui sistem dan manajemen penyelenggaraan yang baik agar pelaksanaan ibadah haji dapat berjalan dengan aman, tertib, lancar, dan nyaman sesuai dengan tuntunan agama serta jemaah haji dapat melaksanakan ibadah secara mandiri sehingga diperoleh haji mabrur. Sementara dalam Peraturan Menteri Agama Republik Indonesia Nomor 10 Tahun 2010 Tentang Organisasi dan Tata Kerja Kementerian Agama, disebutkan bahwa Tugas Kementerian Agama adalah menyelenggarakan urusan di bidang keagamaan dalam pemerintahan untuk membantu Presiden dalam menyelenggarakan pemerintahan negara. Salah satu dari bidang keagamaan tersebut adalah penyelenggaraan ibadah haji.

Adapun dalam pelaksanaanya penyelenggarakan ibadah haji mulai tatacara pendaftaran, penentuan kuota, manasik haji, penentuan keberangkatan sampai kepada waktu pelaksaanan ibadah haji, menurut Kasi Haji dan Umroh Kemenag Kota Bandung setiap tahun selalu diadakan evaluasi untuk perbaikan tahun berikutnya. Tetapi pada kenyataannya masalah 
yang sama selalu muncul kembali sehingga ada kemungkinan baik dari sistem yang harus berubah atau sumber daya manusianya yang masih perlu ditingkatkan. Salah satu contoh permasalah yang masih dianggap tidak efektif adalah tatacara pendaftaran haji. Berdasarkan Peraturan Menteri Agama (PMA) Nomor 6 Tahun 2010 tentang Prosedur dan Persyaratan Pendaftaran Jemaah Haji.

Masalah lain juga yang selama ini banyak dikeluhkan oleh calon jemaah haji adalah kurang efektifnya atau kurang berhasil manasik haji yang diselenggarakan oleh Kementerian Agama tingkat Kabupaten/Kota. Dalam pelaksanaannya manasik tersebut ada yang dilaksanakan langsung oleh Kemenag Kota Bandung dan ada juga oleh Kantor Urusan Agama (KUA). Tahun 2015 manasik haji yang diselenggarakan oleh Kemenag Kota Bandung sebanyak 3 kali dan KUA sebanyak 4 kali. Bahkan manasik praktek masal jemaah haji Kota Bandung pada tahun 2015 tidak dilaksanakan, padahal tahun-tahun sebelumnya selalu ada. Padahal praktek manasik tersebut sangat membantu calon Jemaah haji untuk lebih memahami bagaimana nanti pelaksanaan ibadah haji di tanah suci.

Begitu halnya dalam penentuan kuota haji, sebenarnya dalam penentuan kuota haji sudah ada rujukan secara internasional yaitu jumlah penduduk (Islam) daerah setempat dengan skala perbandingan 1:1.000. Namun pada kenyataan permasalahan penentuan kuota provinsi, $\mathrm{kab} /$ kota selalu timbul setiap tahun. Hal ini terjadi karena adanya perubahan jumlah penduduk muslim di tiap daerah. Perbedaan kuota antara satu daerah dan daerah lain menyebabkan masa tunggu Jemaah haji juga berbeda. Ini yang menyebabkan terjadinya perbindahan pendaftaran calon haji dari satu daerah pidah ke daerah lain, walaupun harus dengan memanipulasi data Kartu Tanda Penduduk (KTP).

Penyelenggaraan ibadah haji dari tahun ke tahun terus mengalami perkembangan dengan segudang permasalahan. Jumlah umat Islam yang menunaikan ibadah haji mengalami peningkatan, adapun sampai akhir tahun tahun 2014 ditambah sampai bulan April 2016, daftar tunggu di kota Bandung pada saat ini, sudah mencapai kurang-lebih dari 27.600 daftar calon jamaah haji perkiraan memasuki tahun 2028-2029. Kalau kuota Jawa Barat tiap tahun kurang lebih sekitar 37.000 orang dengan ditambah ketentuan kebijakan pemerintah Arab Saudi dikurangi 20\% setiap tahunnya dari 2013, maka kuota haji tahun 2016 sudah habis. Namun, seiring dengan kondisi Kabupaten/Kota tentu sangat berbeda-beda daftar tunggunya, karena Jawa Barat menganut kuota haji Kabupaten/Kota. Penentuan kuota haji Kabupaten/Kota di Jawa Barat tersebut diputuskan dengan Surat Keputusan (SK) Gubernur Provinsi Jawa Barat.

Hal lain yang banyak dikeluhkan calon Jemaah hai adalah tidak transparannya penggunaan biaya ibadah haji kepada jamaah yang menyetorkan sebesar 3.589 US\$ perorang pada tahun 2012 adapun tahun 2013-215 sebesar 3.319 US\$ adapun untuk tahun 2016 sebesar 3139US\$ (memang ada penurunan yang setiap tahunnya berubah). Masih harus juga menambah biaya transportasi dari daerah masing-masing ketempat embarkasi seperti Kota Bandung, yang perjamaah harus mengeluarkan untuk pulang pergi antara Bandung dan Bekasi ditahun 2016 Rp. 780.000,- dan biaya lainnya menurut data staf kemenag dan FKBIHI Kota Bandung.

Keadaan tersebut menunjukan bahwa dengan banyaknya calon jamaah haji dari berbagai kalangan dan lapisan masyarakat, dari berbagai latar belakang, maka dengan demikian kebutuhan dan tujuan yang berbeda-beda, menimbulkan masalah tuntutan pelayanan yang bervariasi. Pemerintah menangkap aspirasi yang berkembang dan menyadari akan kebutuhan warga negara yang akan menunaikan ibadah haji sebagaimana ditegaskan dalam Undang-Undang Nomor 13 Tahun 2008 pasal 1 baik yang menyangkut fasilitas, biaya, trasnportasi, kesehatan dan lainnya. Seringkali dijumpai kekecewaan masyarakat pada 
penyelenggaraan pelaksanaan haji, mulai dari masalah biaya penyelenggaraan ibadah haji (BPIH), pelayanan di tanah air sampai pelayanan di tanah suci.

Berbicara penyelenggaraan ibadah haji yang merujuk pada peraturan perundangundangan, maka tentunya berbicara tentang implementasi kebijakan. Grindle (1980) memaknai implementasi kebijakan sebagai sebuah proses administrasi pada umumnya atau sebuah proses dari tindakan administrasi yang dapat ditelusuri pada tingkatan program tertentu. Hal yang sama diungkapkan Edward III (1980) yang mengartikan implementasi kebijakan sebagai tahapan pembuatan kebijakan antara penetapan kebijakan dan konsekuensi kebijakan terhadap orang-orang yang terkena dampak dari padanya. Sementara menurut Jones (1984), setidaknya membutuhkan dua bentuk tindakan yang dilakukan secala berurutan. Pertama merumuskan tindakan apa yang telah merumuskan tindakan yang akan dilakukan. Kedua, melaksanakan tindakan apa yang telah dirumuskan tadi. Implementasi dimaksudkan bahwa keputusan yang dipilih oleh pemerintah dari berbagai alternatif kebijakan ke dalam tindakan. Lebih lanjut Mazmanian dan Sabatier (1983) mengemukakan bahwa implementasi adalah pelaksanaan keputusan kebijakan dasar, biasanya dalam bentuk undang-undang, namun dapat pula berbentuk perintah-perintah atau keputusan-keputusan eksekutif yang penting atau keputusan badan peradilan. Merujuk pada pendapat tersebut, dapat dikemukakan bahwa implementasi melibatkan sejumlah sumber yang termasuk manusia, dana dan kemampuan organisasional yang dilakukan oleh pemerintah maupun swasta (individu atau kelompok) untuk mencapai tujuan yang telah ditetapkan oleh pembuat kebijakan. Ini juga menunjukan bahwa pendapat Mazmanian dan Sabatier tersebut memiliki cakupan yang luas tidak hanya berupa kebijakan dasar yang tertulis namun dapat pula berupa kebijakan yang lebih bersifat teknis yang dibuat untuk melaksanakan kebijakan yang sudah ditetapkan.

Sementara Howlet dan Ramesh (1995) mengungkapkan bahwa implementasi kebijakan adalah proses pelaksanaan program-program dan kebijakan, yang merupakan penterjemah dari rencana-rencana ke dalam praktek. Anderson (1979) mengemukakan bahwa implementasi kebijakan merupakan tahapan yang bersifat praktis dan dibedakan dari formulasi yang dapat dipandang sebagai tahapan yang bersifat teoritis. Impelementasi kebijakan merupakan pelaksanaan dari kebijakan yang dilakukan oleh mesin administratif pemerintah untuk memecahkan masalah yang dihadapi. Mustopadidjaja (1998) yang menyataka bahwa mplementasi kebijakan merupakan suatu yang sangat penting bahkan mungkin jauh lebih penting dari pembuatan kebijakan. Kebijakan akan sekedar berupa impian atau rencana yang tersimpan dalam arsip apabila tidak diimplemenasikan, sehingga akibat dari kurangnya perhatian terhada[ implementasi kebijakan akan menghilangkan mata rantai antara perumusan kebijakan dengan evaluasi kebijakan. Hoogwood (1986) menyatakan pelaksanaan kebijakan itu mampir selalu disesuaikan lagi, hal ini disebabkan karena tujuan dirumuskan terlalu umum, sarana tidak dapat diperoleh pada waktunya dan factor waktu dipillih terlalu optimis, semua ini berdasarkan gambaran situasi yang kurang tepat.

Menurut Albrow (1980) dapat dikemukakan bahwa implementasi kebijakan mengandung unsur-unsur sebagai berikut:

1. Proses, yaitu rangkaian aktivitas atau aksi nyata yang dilakukan untuk mewujudkan sasaran/tujuan yang ditetapkan.

2. Tujuan, yang hendak dicapai melalui aktivitas-aktivitas yang dilaksanakan

3. Hasil atau dampak, yaitu manfaat nyata yang dirasakan oleh kelompok sasaran 
Dengan demikian studi implementasi kebijakan publik pada prinsipnya berusaha memahami apa yang senyatanya terjadi sesudah sesuatu program dirumuskan yakni peristiwaperistiwa dan kegiatan-kegiatan yang terjadi setelah proses kebijakan negara, baik menyangkut usaha-usaha mengadministrasikan maupun usaha-usaha untuk memberikan dampak tertentu pada msyarakat ataupun peristiwa-peristiwa. Dari beberapa proses kebijakan, implementasi kebijakan merupakan aspek penting dari keseluruhan proses kebijakan. Biasanya impelementasi dilaksanakan setelah sebuah kebijakan dirumuskan secara jelas, termasuk jangka pendek, jangka menengah, dan jangka panjang.

Selanjutnya menurut Syukur (1986) dan Wahab (1997) ada tiga unsur penting unsur dalam proses implementasi yaitu (i) adanya program atau kebijakan yang dilaksanakan; (ii) Target group yaitu kelompok masyarakat yang menjadi sasaran dan diharapkan akan menerima manfaat dari program ini, perubahan atau peningkatan; (iii) Unsur pelaksanaan (implementer) baik organisasi atau perorangan untuk bertanggungjawab dalam memperoleh pelaksanaan dan pengawasan dari proses implementasi tersebut. Adapun implementasi program pemerintah dapat dipandang dari tiga sudut yang berbeda yaitu pertama, pemrakarsa kebijakan/pembuat kebijakan; kedua, pejabat-pejabat pelaksana di lapangan dan yang ketiga, aktor-aktor perorangan di luar badan-badan pemerintahan kepada siapa program itu dituju, yakni sekelompok sasaran (target group).

Pelayanan penyelenggaraan ibadah haji sebenarnya setiap tahun selalu diupayakan agar lebih baik. Upaya perbaikan meliput penggunaan sistem daftar tunggu guna menjamin kepastian keberangkatan jamaah calon haji; mempersingkat jarak tempuh melalui penerbangan langsung Jakarta-Madinah (sebelumnya melalui Jeddah), sehingga lebih efisien dan mengurangi beban fisik dan psikologis para jamaah haji; dan disediakan makan gratis selama sembilan hari ketika bermukim di Madinah, akan tetapi tetap saja masih ada meninggalkan beberapa persoalan. Adapun fasilitas di Makkah mulai tahun 2015 selain pemondokan dan transfortasi, disediakan makan dalam sehari satu kali (siang hari). Ini merupakan bagian dari upaya peningkatan pelayanan kepada Jemaah haji.

Adapun kenyataan yang lain dalam penyelenggaraan ibadah haji menurut Jemaah haji tahun 2016 masih belum memuaskan sesuai dengan harapan. Hal tersebut dapat dilihat dari beberapa catatan seperti adanya perbaikan pelayanan di Indoensia, perbaikan kondisi pemondokan, baik di Indonesia yaitu di Asrama Haji Bekasi dan Pemondokan di Makkah dan Madinah, perlunya perbaikan katering bagi jamaah yang belum ada perubahan dalam kurun waktu yang sudah lama, perlunya peningkatan fasilitas pelayanan pendukung di Arab Saudi seperti transportasi dan kesehatan, perlunya mengurangi tambahan biaya yang dibebankan kepada jemaah haji selain $\mathrm{ONH}$, dan masih perlunya pemahaman pelaksanaan ibadah haji dan situasi dan kondisi serta adat dan istiadat daerah Makkah dan Madinah.

Adapun untuk meningkatkan lembaga penyelenggaraan ibadah haji yang dikoordinir oleh Kementerian Agama RI telah dilakukannya pelatihan manajemen kepada pengelola lembaga, bantuan sarana dan prasarana, serta pemberian bantuan untuk kegiatan operasional. Sedangkan janji Menteri Agama RI saat ini menyatakan akan meningkat kwalitas pelayanan haji. Bahkan, pelayanan yang diberikan kepada jama'ah haji akan mengalami peningkatan dibanding tahun-tahun sebelumnya. Penyelenggaraan haji Indonesia akan berjalan dengan baik apabila dikelola oleh sebuah lembaga yang kuat dan diusung dengan sumber daya manusia yang jujur, amanah, bertanggungjawab, kompeten, dan berorientasi pada pemberian pelayanan terbaik serta perlindungan kepada jamaah haji. Hanya dengan cara itulah jamaah haji Indonesia dapat terhindar dari permainan tangan-tangan kotor. 
Namun demikian, masih didapati berbagai kelemahan, kekurangan yang dianggap gagal pada item tertentu dalam penyelenggaraan ibadah haji yang diamati peneliti. Yang kesemuanya bermuara kepada implementasi kebijakan tentang penyelenggaraan ibadah haji. selain masih belum transparannya penggunaan dana ibadah haji. Kurangnya respons terhadap berbagai lembaga non pemerintah seperti Ikatan Persaudaraan Haji Indonesia (IPHI), Kelompok Bimbingan Ibadah Haji (KBIH), Majelis Ulama Indoensia (MUI) yang mengontrol haji, keluhan para jemaah serta kurangnya pengawasan, bahkan kebijakan Menteri Agama Republik Indonesia membatasi masyarakat yang sudah pernah menunaikan ibadah haji, hal ini telah memicu masalah dalam penyelenggaraan ibadah haji di Indonesia khususnya di Kota Bandung.

Pemerintah melalui Kementerian Agama RI Kota Bandung, seharusnya dapat melaksanakan Implementasi Kebijakan Penyelenggaraan Ibadah Haji secara optimal dan efektif, dengan tidak mengabaikan aturan legal formal yang sudah ditetapkan selama ini. Berdasarkan latar belakang penelitian yang dikemukakan di atas, dapat dirumuskan masalah pokok penelitian dalam bentuk pernyataan masalah implementasi kebijakan penyelenggaraan ibadah haji belum berhasil, sehingga mengakibatkan penyelenggaraan ibadah haji khususnya di Kota Bandung belum berhasil. Dengan demikian, berdasarkan pernyataan masalah tersebut, penelitian ini bertujuan untuk menganalisis faktor keberhasilan implementasi kebijakan penyelenggaraan ibadah haji di Kota Bandung.

\section{Metode Penelitian}

Pendekatan yang digunakan dalam penelitian ini adalah pendekatan kualitatif, karena bagi penulis pendekatan kualitatif lebih mempunyai kedalaman dan ketajaman analisis dalam mengungkapkan fenomena serta fakta terhadap dampak dari implementasi kebijakan penyelenggaraan haji di Kota Bandung. Penggunaan pendekatan kualitatif ini juga disesuaikan dengan karakteristik yang ada bahwa peneliti secara langsung terlibat di lokasi penelitian melalui pengamatan serta participant observation. Penggunaan pendekatan kualitatif menekankan kepada permasalahan mengenai apa adanya (das sein) dengan kenyataan yang ada di lapangan melalui kata-kata lisan atau tertulis, dari orang dan perilaku yang diamati. Pada saat yang sama peneliti akan memahami tentang karakteristik lapangan yang berintegrasi dengan kehidupan masyarakat yang akan diteliti. Adapun tujuan pemilihan pendekatan kualitatif ini adalah untuk memahami bagaimana proses dan mengungkapkan makna dari setiap fenomena menurut persepsi masyarakat dan pemerintah dengan dukungan teoritik yang ada dan dibangun kerangka pikir, premis dan hipotesis kerja.

Jenis data dari penelitian ini adalah data primer dan data sekunder. Data primer berasal dari informan berupa informasi dan data hasil wawancara dengan pihak yang berkepentingan dan pelaku utama baik dari Kementrian Agama Republik Indonesia, pemerintah pusat dan daerah serta masyarakat yang berhubungan dengan penyelenggaraan haji di Kota Bandung. Data sekunder bersumber dari artikel, studi literatur, dokumen dan foto, data statistik, arsip baik dari pihak pemerintah maupun masyarakat serta publikasi media massa. Pengumpulan dan pencatatan data dilakukan dengan melakukan observasi langsung ke lapangan dengan melihat hasil kebijakan yang sedang berjalan. Pelaksanaan observasi lapangan disertai juga dengan wawancara kepada pihak-pihak yang terkait yang terlibat langsung dalam implementasi kebijakan. Selanjutnya hasil observasi dan wawancara ditindaklanjuti dengan pengecekan pada literatur dengan melakukan studi dokumentasi. 
Pengolahan data dimulai dengan menelaah seluruh data yang telah dikumpulkan dari berbagai sumber yaitu berupa data hasil pengamatan, wawancara, studi kepustakaan, dan arsip dengan memilihnya untuk menemukan data yang diperlukan. Kemudian dari masing-masing data yang telah ditelaah dari masing-masing sumber itu dibuat abstraksi berupa rangkuman inti. Kategorisasi data dikelompokkan atas dasar pikiran, intuisi, dan pendapat. Selanjutnya menempatkan data pada kategori masing-masing. Metode yang digunakan dalam analisis adalah mengkomporasikan data yang diperoleh dari informan dan dokumentasi.

\title{
Hasil dan Pembahasan
}

\section{Implementasi Kebijakan Penyelenggaraan ibadah haji di Kota Bandung}

Dalam sepuluh tahun terakhir penyelenggaraan haji berlangsung, animo masyarakat yang ingin menunaikan ibadah haji dari tahun ke tahun selalu meningkat. Pengecualian terjadi pada tahun 1999 ketika porsi tersebut tidak terpenuhi akibat krisis moneter yang sedang mencapai 70.462 orang, padahal kuota nasional sebanyak 202.000 orang. Pada tahun 2013 Pemerintah Indonesia mendapat surat pemberitahuan dari Pemerintah Arab Saudi tentang kebijakan pengurangan kuota haji sebesar 20\% untuk seluruh Negara tanpa terkecuali karena adanya proyek pembangunan masjidil harom yang memakan waktu penyelesaian selama 4 (empat) tahun. Kuota jamaah haji Indonesia yang disepakati dalam MoU Persiapan Haji 1434 H/2013 M sebanyak 211.000 orang berdasarkan jumlah penduduk Republik Indonesia yang tercatat di PBB. Karena ada pemotongan tersebut, maka mengalami pengurangan kuota jamaah haji sebanyak 20\% dari 211.000 jamaah, jumlah jamaah haji yang akan diberangkatkan ke Tanah Suci pada tahun 1434 H/2013 M. sebanyak 168.800 jamaah, yang terdiri dari 155.200 jamaah haji regular dan 13.566 jamaah haji khusus yang diselenggarakan oleh 138 PIHK pada tahun 2016.

Adapun implementasi kebijakan dalam penentuan kuota sudah berdasarkan UU Tahun 2008 No 13. Namun dalam kenyataannya jumlah penduduk dibanding dengan peminat haji di sebagian daerah ternyata tidak proporsional. Sebagaimana hasil wawancara dengan Kasi Haji dan Umroh Kemenag Kota Bandung, sebagaimana berikut ini,

\begin{abstract}
"Tidak ada perubahan Undang-Undang No 13 Tahun 2008 tentang Penyelenggaraan Ibadah Haji, hanya isinya saja yang berubah, ditambah dengan regulasi KMA tentang penyelenggaraan ibadah haji. Apabila berbicara masalah hambatan, pasti ada saja, hanya ukuran atau beratnya, atau mungkin kurang sesuai, itu yang jadi permasalahan. Contohnya, Pemeriksaan Kesehatan, pembuatan paspor, pelunasan dengan 2 gelombang, begitu juga biaya pelaksanaan teknis, bahkan dengan jatahnya kuota Kota Bandung dengan kuota gabungan dari daerah lain ke Kota Bandung antara keharusan mengirimkan dokumen paspor jemaah dengan jadwal pelunasan waktunya bersamaan. Seharusnya yang diharapkan pengiriman dokumen paspor jemaah dikirim setelah selesai pelunasan.
\end{abstract}

Berdasarkan wawancara diatas tentang permasalahan dalam penyelenggraan ibadah haji, secara historis dari tahun ke tahun menunjukan telah secara responsif diatasi oleh Pemerintah Indonesia. Bahkan tidak berhenti di situ, saat inipun bergulirnya wacana penyelenggaraan haji yang modern dengan mengedepankan kualitas pelayanan prima, telah mendorong DPR RI untuk mengusulkan inisiatif Rancangan Undang-undang perubahan UU No. 17/1999 tentang Penyelenggaraan Haji. Batang tubuh Perubahan Undang-undang Nomor 17 Tahun 1999 tentang Penyelenggaraan Ibadah Haji memiliki jumlah pasal yang lebih banyak 
(kurang lebih dua kali lipat dibandingkan UU No.17 Tahun 1999), yaitu terdiri dari 17 Bab dengan 60 pasal. Di dalam RUU Perubahan UU No. 17 Tahun 1999, telah diakomodirnya beberapa harapan masyarakat, seperti mengenai pemisahan peran pengawasan yang selanjutnya diserahkan kepada Badan Pengawas Haji dan juga pemisahan pengelolaan Dana Abadi Umat yang dibentuk untuk maksud tersebut. Namun demikian Pemerintah dalam hal ini Kementerian Agama tetap memegang peran dalam pengambilan keputusan di satu sisi, dan secara bersamaan juga masih memegang peran sebagai operator atau pelaksana penyelenggaraan ibadah haji.

Dampak dari adanya revisi menjadi UU No. 13 Tahun 2008 dari UU No. 17 Tahun 1999, yaitu di antaranya merevisi pemerintah terlalu memonopoli kegiatan Penyelenggaraan ibadah Haji. Dimana regulasi, pelaksana, dan pengawasan bertumpuk pada satu lembaga atau Kementerian yaitu Kementerian Agama Republik Indonesia. Akumulasi kewenangan mengakibatkan terjadinya tumpang tindih kebijakan, antara pemegang kebijakan strategis dengan pelaksana teknis, sehingga memunculkan banyak kekurangan dalam penyelenggara ibadah haji. Lahirnya UU yang baru No. 13 Tahun 2008 justru tidak lebih baik dari UU sebelumnya yaitu UU No. 17 Tahun 1999, dan semakin mengindikasikan adanya praktik KKN. Potensi penyimpangan dalam penyelenggaraannya juga banyak ditemukan di UU baru ini, di antaranya sistem perekrutan calon anggota Komisi Pengawas Haji Indonesia sangat membuka ruang intervensi bagi Menteri Agama.

Adapun UU No. 13 Tahun 2008 yang dianggap masih banyak kelemahan, maka pada tahun 2014 DPR RI dan Pemerintah merancang Undang-Undang No. 34 Tahun 2014 tentang Penyelenggaraan Ibadah Haji. Yang menarik, pada UU tersebut dinyatakan bahwa tata kelola keuangan ditangani oleh badan khusus yaitu Badan Pengelola Keuangan Haji (BPKH). Badan ini bersifat mandiri dan bertanggung jawab langsung kepada Presiden melalui Menteri Agama. BPKH bertugas mengelola keuangan haji yang meliputi penerimaan, pengembangan, pengeluaran dan pertanggungjawaban keuangan haji, dan berwenang menempatkan atau menginvestasikan keuangan haji dengan prinsip syariah. Dengan lahirnya UU ini diharapkan tidak ada lagi monopoli penyelenggaraan ibadah haji oleh lembaga tertentu sehingga berdampak kepada penyelenggaraan ibadah haji yang murah, tertib, aman dan nyaman.

Walaupun UU Haji telah diperbarui, kenyataannya monopoli penyelenggaraan ibadah haji tetap tidak tersentuh. Kementerian Agama masih menjadi aktor satu-satunya penyelenggaraan ibadah haji. Padahal sistem monopoli inilah yang menjadi tidak jelas masalah biaya haji yang harus di bayar oleh calon jamaah yang akan naik haji karena tidak terbukanya peran swasta untuk aktif menentukan biaya haji tersebut. Hal ini mengakibatkan adanya monopoli dalam setiap pemenuhan poin-poin keperluan haji mulai dari pengadaan barang, pesawat maupun makanan katering dan penempatan hotel baik di Madinah dan juga Makkah.

Dari penjelasan di atas, bahwa penyelenggaraan haji masa periode 1999 sampai sekarang sangat banyak mengalami perubahan penyelenggaraan ibadah haji yang sesuai dengan harapan masyarakat muslim Indonesia, bahwa penyelenggaraan ibadah haji merupakan tugas Negara (Pemerintah). Namun Undang-Undang tersebut masih memonopoli penyelenggaraan, yaitu sebagai pembuat kebijakan, pelaksana dan pengawas. Kondisi tersebut melatarbelakangi lahirnya Rancangan Undang-undang (RUU) yang sangat jelas dalam perubahan penyelenggaraan ibadah haji, khususnya masalah keuangan yang dikelola oleh suatu badan yang diberi nama Badan Pengelola Kuangan Haji. RUU yang menurut rencana akan disahkan menjadi Undang-undang pada tahun 2015 ini begitu ditunggu-tunggu implementasinya oleh masyarakat karena diharapkan akan bisa mengatasi berbagai 
permasalahan penyelenggaraan ibadah haji selama ini, akan tetapi sampai saat ini belum ada berita pengesyahan RUU untuk penyelenggaraan ibadah haji.

Tingkat keberhasilan sebuah penyelenggaraan ibadah haji dapat dilihat dari beberapa faktor. Hal tersebut dapat dilihat misalnya dari a) ketepatan waktu, yaitu jumlah jemaah haji yang terdaftar dapat berangkat sesuai dengan tahun yang ditentukan, b) dukungan fasilitas, yaitu setiap Jemaah haji memperoleh layanan fasilitas dan akomodasi sesuai dengan standar yang berlaku, c) kepuasan pelayanan, yaitu setiap Jemaah haji dapat merasakan pelayanan yang baik sehingga menimbulkan perasaan kepuasan lahir dan batin sejak pemberangkatan hingga kepulangannya. Sebagaimana hasil wawancara bersama dengan, adalah hasil wawancara dengan Ketua Forum KBIHI Kota Bandung tentang pelaksanaan haji yang ideal.Pertama, harus dilihat terlebih dahulu dari tujuan pelaksanaan ibadah haji. Terdapat beberapa kata kunci yang senantiasa disampaikan oleh Kementerian Agama bahwa di dalam pelaksanaan ibadah haji itu ukuran keberhasilannya ditentukan oleh setiap jemaah haji yang terdaftar dan bisa berangkat di tahun sesuai seharusnya berangkat, jemaah haji harus mendapat fasilitas akomodasi sesuai dengan ketentuan, dan mendapatkan pelayanan haji sebaik-baiknya dan bisa kembali ke tanah air dengan selamat. Mulai tahun 2016 sudah dimulai terasa ada peningkatan seperti kontrol kesehatan yang lebih ketat dan itu bagus, ada beberapa perbaikan dari sisi standar pelayanan. Namun yang masih menjadi masalah adalah biaya. Biaya haji itu seharusnya kita punya referensi. Artinya, kalau kita menetapkan biaya ibadah haji, apakah sudah memenuhi standar atau belum. Mungkin sebagian besar tidak tahu karena informasi ini tidak secara umum dipublikasikan, kalau kita membandingkan dengan biaya negara terdekat saja Malaysia itu jauh bedanya.

Sedangkan kebijakan yang ideal dalam implementasi kebijakan penyelenggaraan haji di Kementerian Agama Kota Bandung menurut seorang Ketua KBIH di Kota Bandung, yaitu pada dasarnya di Kota Bandung itu ada 2. Pertama, di Kamenag dan kedua, Forum KBIH. Artinya kedua lembaga ini yang mendukung penyelenggaraan haji di Kota Bandung. Tentunya diharapkan kedua lembaga ini menjadi lembaga yang sinergis untuk memajukan penyelenggaraan KBIH Kota Bandung. Hanya saja dalam hal ini perlu juga dilihat sejauhmana peran-peran itu bisa berfungsi. Tentunya diharapkan sesuai dengan alurnya sesuai dengan keberadaan lembaga itu sehingga masing-masing bisa berfungsi. Berbicara komponen kebijakan yang ideal, apakah undang-undang atau aturan yang diberlakukan untuk pelaksanaan ibadah haji sudah sesuai dengan harapan. Undang-Undang Nomor 13 Tahun 2008 ini sebetulnya sudah hampir mendekati kepada titik ideal, hanya mungkin perlu beberapa tambahan perbaikan untuk lebih sempurnanya pelayanan dari pemerintah terhadap jemaah haji, terkhusus untuk Kota Bandung. Salah satunya adalah kurang sosialisasinya dari aturan ini kepada seluruh jamaah. Bisa jadi, apabila sebagai pelaksana, dalam hal ini pemerintah, siap dengan jumlah yang lebih banyak maka itu akan memberikan dampak pada pelayanan yang harus lebih prima. Tetapi sebetulnya bukan masalah jumlah tetapi masalah kesiapannya. Jadi sebetulnya bukan di jumlah, tinggal kesiapan pemerintah untuk melayani jemaah dengan jumlah sekian, dan harapannya, untuk Indonesia ini memang harus ditambah. 
Tabel 1

Data Pemberangkatan Pemberangkatan Jama'ah Haji Kota Bandung 2014 - 2016

\begin{tabular}{ccccccc}
\hline Tahun & $\begin{array}{c}\text { Quota } \\
\text { Reguler }\end{array}$ & Tphd & $\begin{array}{c}\text { Gabungan } \\
\text { Masuk }\end{array}$ & $\begin{array}{c}\text { Gabungan } \\
\text { Ke Luar }\end{array}$ & $\begin{array}{c}\text { Batal } \\
\text { Berangkat }\end{array}$ & $\begin{array}{c}\text { Total } \\
\text { Berangkata }\end{array}$ \\
2014 & 1696 & 15 & 669 & 94 & 2 & 2284 \\
2015 & 1731 & 39 & 690 & 125 & 10 & 2325 \\
2016 & 1731 & 28 & 323 & 93 & 2 & 1987 \\
\hline
\end{tabular}

Catatan : Tahun 2016 total jama'ah gabungan ada 675 orang tapi sebanyak 352 tidak diberkenankan gabung dengan alasan regulasi.

\section{Sumber : FK KBIHI Kota Bandung}

Sebagaimana hasil wawancara diatas bahwa betapa rumitnya mengenai biaya yang harus dibayarkan oleh jamaah dari yang seharusnya, dikarnakan kurangnya keterbukaan pemerintah dalam masalah biaya kepada jamaah haji, sehingga yang mereka bayarkan seolaholah sudah maksimal dengan harapan pelayanan, pembinaan dan perlindungan/keamanan bisa direalisasikan dengan baik. Bahkan dengan adanya Keterbatasan kuota jamaah haji Indonesia menimbulkan konsekwensi tidak semua peminat haji dapat menunaikan ibadah haji pada tahun yang diinginkan bahkan ada yang menunggu sampai diatas 25 tahun seperti di kalimatan, adapun untuk Kota bandung waktu tunggu calon jamaah haji sekitar 10 sampai 12 tahun masa tunggu bagi calon jamaah haji untuk jamaah haji reguler. Oleh karena itu kesempatan pendaftaran menunaikan ibadah haji diutamakan kepada peminat yang sehat jasmani dan rohani serta mampu melunasi BPIH sesuai ketentuan peraturan perundang-undangan. Menurut Direktorat Jenderal Bimas Islam dan Penyelenggaraan Haji Departemen Agama RI, kuota atau jamaah haji yang berangkat menunaikan ibadah haji terbagi dalam 3 jenis, yaitu jamaah regular, jamaah khusus (ONH Plus) dan jamaah lain-lain (kloter maupun non-kloter yaitu penyelenggara).

Seperti diketahui bahwa saat ini pemberangkatan jamaah haji dari Indonesia ke tanah suci dilakukan melalui 11 embarkasi yang terbagi dalam 3 zona, yaitu:

- Zona I : Banda Aceh, Medan, Batam dan Padang

- Zona II : Jakarta, Solo, Surabaya dan Palembang

- Zona III : : Balikpapan, Banjarmasin dan Makasar

Perkembangan jamaah haji menurut Kementerian Agama RI masih didominasi oleh lima provinsi yang juga memiliki jumlah penduduk yang banyak. Kelima provinsi itu adalah Jawa Timur, Sulawesi Selatan, Jawa Barat, Jawa Tengah dan DKI Jakarta. Berdasarkan kuota per provinsi, pemerintah membuat keputusan pembagian kuota setiap tahunnya.

Berdasarkan wawancara diatas ternyata dalam implementasi kebijakan yang ada, dengan realita kebutuhan penyelenggaraan ibadah haji sangatlah jauh dilihat dari kebutuhan jamaah dalam pelayanan dan pembinaan yang real yang belum berhasil dilakukan oleh pemerintah sesuai Undang-Undang Nomor 17 Tahun 1999 terdiri atas 16 bab dengan 30 pasal. Isinya mengatur tentang Ketentuan Umum, Asas dan Tujuan, Pengorganisasian, Baiya Penyelenggaraan Ibadah Haji, Pendaftaran, Pembinaan, Kesehatan, Keimigrasian, Transportasi, Barang Bawaan, Akomodasi, Penyelenggaraan Ibadah Haji Khusus, Penyelenggaraan Perjalanan Ibadah Umroh, Ketentuan Pidana, Ketentuan Peralihan dan Ketentuan Penutup. Meskipun demikian, penyelenggaraan haji masih terus diwarnai oleh 
kemelut serta persoalan yang seringkali berulang tanpa memperoleh solusi yang tuntas dan komprehensif. Munculnya berbagai persoalan dalam penyelenggaraan ibadah haji selama ini bukan hanya semata-mata persoalan teknik-kasuistik yang disebabkan oleh buruknya manajemen penyelenggaraan haji pemerintah, namun lebih dari itu, UU tersebut ternyata memiliki banyak kelemahan yang berpotensi melahirkan kerancuan sistemik yang berdampak pada buruknya penyelenggaraan haji di Indonesia. Walaupun dengan adanya perubahan menjadi UU No.13 Tahun 2008.

Hal ini terlihat dari peran KBIH yang dianggap oleh jamaah lebih bisa melayani secara langsung terhadap jamaah haji yang ikut dalam $\mathrm{KBIH}$ tersebut, akan tetapi pemerintah sementara ini menutup mata kepada peran $\mathrm{KBIH}$ yang nyata-nyata sangat membantu bagi penyelenggaraan ibadah haji khususnya di Kota Bandung. Adapun yang dibutuhkan dari KBIH ada kebijakan kelonggaran bagi para pembimbing dari KBIH masing-masing utuk mudah dalam tahun tersebut bisa memberangkatkan pembimbingnya walaupun dengan biaya sendiri, dalam hal ini untuk membantu pemerintah dalam pelayanan pembinaan baik dari sebelum berangkat dan proses ibadah haji di arab saudi sampai pulang kembali ke tanah air. Sampai sekarang ternyata masih belum ada perhatian walaupun sudah diusulkan melalui FKBIHI Pusat dengan berbagai alasan yang hanya sifatnya harapan semata. Adapun kurang baiknya penyelenggaraan ibadah haji karena adanya kerancuan UU yang menyatakan bahwa pemerintah memegang peran sebagai Pemangku kebijakan, pelaksana sekaligus pengawas. Monopoli kekuasaan dan kewenangan ini mengakibatkan tidak adanya sistem pengawasan dan sistem keseimbangan, dan berkecenderungan mengakibatkan penyalahgunaan wewenang yang akan berimbas pada lahirnya perlakuan ataupun praktek yang tidak adil. Sebagai imbasnya ada para pejabat Kementerian Agama RI harus beruusan dengan hukum, dikarenakan monopoli pemerintah dalam penyelenggaraan haji menyebabkan kerancuan dalam pengorganisasian haji. Peran pemerintah memegang kendali dari mulai regulasi hingga ke pelaksanaan teknis penyelenggaraan sangat jelas akan tetapi masih saja ada hal yang selalu tidak beres dalam pelaksanaannya. Hal ini mengakibatkan tumpang tindih antara berbagai kepentingan yang bermuara pada otoritas tunggal Menteri Agama.

Saat ini standar kesuksesan penyelenggaran haji bersifat artifisial, yakni hanya menyangkut berhasilnya pemerintah dalam memberangkatkan serta memulangkan kembali jamaah haji ke embarkasi masing-masing. Aspek bimbingan, pelayanan serta perlindungan jamaah yang semestinya menjadi kunci terlaksananya ibadah secara baik, masih belum mendapatkan perhatian yang semestinya. Bahkan menjadi tanggung jawab KBIH secara moril kepada jamaah yang dibawanya.

Kekacauan berikutnya dalam kaitannya dengan Biaya Penyelenggaraan Ibadah Haji (BPIH), yaitu Undang-undang Nomor 17 tahun 1999 tidak mengatur secara jelas mana biaya yang harus ditanggung oleh jamaah dan mana yang harus ditanggung oleh Negara. Bahkan menurut UU ini, seluruh pembiyaan haji dibebankan kepada jamaah melalui BPIH. Padahal berdasarkan Pasal 3 ditetapkan bahwa 'pemerintah berkewajiban melakukan pembinaan, pelayanan dan perlindungan dengan menyediakan fasilitas, kemudahan, keamanan dan kenyamanan yang diperlukan oleh setiap warga Negara yang melaksanakan ibadah haji'. Tidak adanya transparasi dalam porsi penentuan Biaya Penyelenggaraan Ibadah Haji (BPIH) telah memunculkan kesan kental akan telah terjadinya praktik pengkomersialan haji. Transportasi dan akomodasi di mekkah merupakan komponen vital dan terbesar dalam pembiyaan haji. Namun sayangnya, penunjukan pelaksana transportasi dan akomodasi hanya ditentukan oleh kebijakan Menteri. 
Dari hasil wawancara diatas, dapat dijelaskan menyangkut kebijakan yang ideal, telah terlaksana dengan baik, walaupun hambatan itu selalu lau ada, seperti persoalan tersebut di atas seperti pengurusan paspor dan teknis lainnya belum sesuai dengan program yang sudah ditetapkan melalui KMA yang pada prinsipnya belum berjalan sebagai mana mestinya pada tahap implementasi di tingkat kota dan kabupaten khususnya Kota Bandung. Sehingga masih dibutuhkan koordinasi dan penjabaran dari tingkat pusat ke tingkat bawah agar dalam pelaksanaannya sesuai dengan program dan harapan masyarakat, dengan demikian jika kita merujuk kepada pemahaman defenisi mengenai Implementasi kebijakan, maka kebijakan yang ideal adalah merupakan salah satu tahap dalam proses kebijakan publik. Biasanya implementasi dilaksanakan setelah sebuah kebijakan dirumuskan dengan tujuan yang jelas dan merupakan suatu rangkaian aktifitas dalam rangka menghantarkan kebijakan sehingga kebijakan tersebut dapat membawa hasil sebagaimana yang diharapkan.

\section{Simpulan}

Berdasarkan hasil dan pembahasan penelitian yang dilakukan, dapat diperoleh kesimpulan bahwa implementasi kebijakan penyelenggaraan ibada haji di Kota Bandung tahun 2016 belum terlaksana dengan baik. Hal tersebut dikaitkan dengan suatu realitas yang paradoks terhadap kebijakan ideal yang meliputi aspek pelayanan, pembinaan dan perlindungan terhadap jamaah haji Indonesia yang tercantum dalam Undang - Undang Nomor 17 Tahun 1999 dan perubahan Undang-Undang Tahun 2008 Nomor 13. Realitas tersebut belum semuanya menjadi tanggung jawab pemerintah dalam melaksanaan kewajibannya, karena selama ini pemerintah hanya mengurusi yang sifat administratif semata. Sehingga masih ada yang terabaikan khususnya pembinaan, pelayanan dan perlindungan terhadap jamaah secara langsung. Disamping itu kebijakan yang ideal melalui program kerja yang dijabarkan melalui KMA yang meliputi aspek identifikasi, sosialisasi dan proses penyusunan rencana program telah terbukti belum berjalan dengan baik. Terbukti KBIH sangat membantu sekali dari mulai di tanah air proses perjalanan ibadah haji sampai pemulangan, bahkan pasca hajian, akan tetapi peran KBIH masih dianggap bukan bagian dari peran Penyelenggara ibadah haji sehingga masih dikesampingkan akan perannya.

\section{Referensi}

Abdurrahman, M. (2009). Bersujud Di Baitullah: ibadah haji mencari kesalehan hidup.

Darwis. (2005). Ibadah Haji dalam Sorotan. Bandung: Ar-Rahmah.

Dien, M. (2002). Pengangkutan Jemaah Haji Indonesia Masa Kolonial (Akhir Abad XIX, Awal Abad XX). Jakarta : UIN Syarief Hidayatullah

Dunn, W.N. (2009). Analisa Kebijakan Publik. Terjemah Muhajir Darwin. Yogyakarta: Hanindita Graha Widia.

Edwards III, G.C. (1980). Implementing Public Policy. Washington: Congressional Quarterly Inc.

Grindle, M.S. (ed). (1990). Politics and Apolicy Implementation in Third World, New Jersey: Princetown University Press.

Hanan, A.L., Nidjam, A. (2006). Manajemen Haji. Jakarta: Mediacita

Howlett, M., Ramesh, M. (1995). Studying Public Policy: Policy Cycles and Policy Subsystem. Oxford : Oxford University Press. 
Islamy, I.M. (2000). Prinsip-Prinsip Perumusan Kebijaksanaan Negara. Jakarta: Bina Aksara.

Kementerian Agama. (2006). Panduan Perjalanan Haji. Jakarta : Dirjen Penyelenggara Haji dan Umrah.

Majid, D. (2008). Berhaji di Masa Kolonial. Jakarta : CV. Sejahtera.

Mazmanian, D. A. \& Paul. A.S. (1983). Implementation and Public Policy. London: Scott, Foresman and Company.

Moleong, L.J. (1998). Metode Penelitian Kualitatif. Bandung: PT Remaja Rosda Karya.

Putuhena, S. (2006). Historiografi Haji Indonesia. Jogjakarta : LKiS.

Rosadi, A. (2012). Sejarah, Perkembangan dan Pemikiran Pengelolaan Ibadah Haji di Indonesia. Bandung : CV. Arvino Raya.

Saepuloh, A. (2015). Praktik Penyelenggaran Ibadah Haji Khusus (PIHK): Memadukan Kepentingan Ibadah, Bisnis dan Negara, Bandung: FISIP UNPAD.

Saleh, A.C. (2008). Penyelenggaraan Haji Era Reformasi (Analisis Internal Kebijakan Publik Departemen Agama). Tanggerang, Alvabet.

Van Meter, D.S., Van Horn, C.E. (1975). The Policy Implementation Process: A Conceptual Framev:ork. London: Sage Publications Inc. 